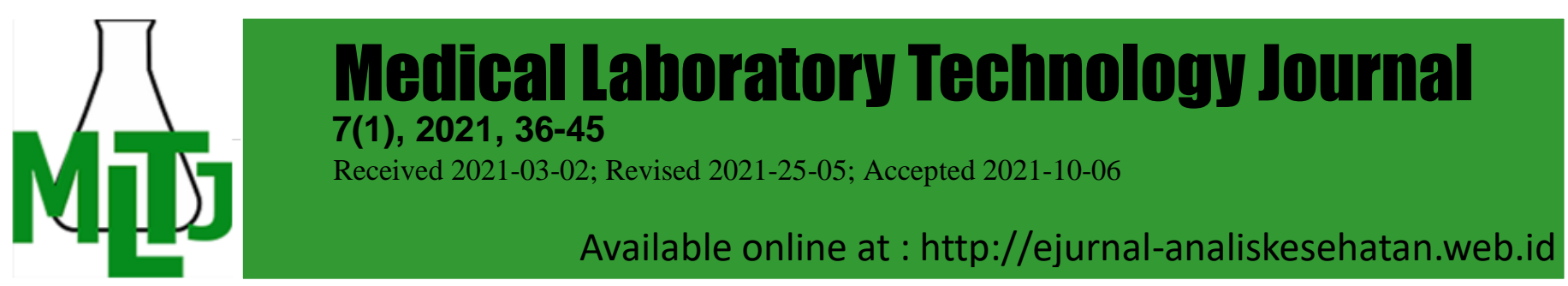

\title{
Utilization of Activated Corn Cob (Zea Mays) as an Improved Adsorbent for Reducing Chemical Oxygen Demand (COD) Value from Waste of the Sasirangan Industry
}

\author{
*Erfan Roebiakto, Noor Hikmah Damayanti, Neni Oktiyani, Nurlailah \\ Medical Laboratory Technology Poltekkes Kemenkes Banjarmasin. \\ Mistar Cokrokusumo Street 4a Banjarbaru Indonesia \\ *Email: erfan.roebiakto4@gmail.com \\ DOI: $10.31964 / \mathrm{mltj} . v 7 i 1.351$
}

\begin{abstract}
Liquid waste from sasirangan industrial activities has a high enough Chemical Oxygen Demand pollutant power; if it is directly discharged into water bodies, it can damage the environment and harm health. One of the first processes needs to be done by using activated corn cobs (Zea mays). This study aims to analyze the ability of corn cobs charcoal to reduce levels of Chemical Oxygen Demand and increase the $\mathrm{pH}$ of sasirangan waste so that the results of this study can be an alternative to natural-based sasirangan waste treatment. This type of research is a pure experiment with a research design in One Group Pretest Postest Design. The research material used was sasirangan industrial waste in Manarap Village, Kertak Hanyar District, Banjar Regency, South Kalimantan, Indonesia. Chemical Oxygen Demand levels were determined by the closed reflux titrimetry method. The results showed that the addition of the highest dose of activated corncob charcoal $(50 \mathrm{~g})$ reduced the largest turbidity by 35 percent, increased the $\mathrm{pH}$ by 72 percent, and reduced the color intensity by 33 percent. The conclusion is that the addition of corncob-activated charcoal at a dose of $30 \mathrm{gr}, 40 \mathrm{gr}, 50 \mathrm{gr}$ can reduce levels of Chemical Oxygen Demand, respectively, namely 24 percent, 35 percent, and 33 percent. An increase in $\mathrm{pH}$ was found at the same dose of 46 percent, 62 percent, and 72 percent, respectively. There is an effect of increasing the mass of activated charcoal from corn cobs on the Chemical Oxygen Demand levels in the sasirangan industrial waste with a significance value of 0.007 . It is suggested to use corn cobs-activated charcoal for the pretreatment stage of sasirangan industrial waste treatment.
\end{abstract}

Keywords: Chemical Oxygen Demand; corncobs; sasirangan industrial waste

\section{INTRODUCTION}

The industrial sector in Indonesia is growing rapidly. The industrialization process of Indonesian society is accelerating with the establishment of various companies and workplaces. The industrial sector is a pioneer in community economic development (Ginting, 2007). The industry in South Kalimantan has 50,198 business units, most of which are Sasirangan industries, with as many as 70 business units. The Sasirangan industry is designated one of the top ten commodities in South Kalimantan (Putra, 2011). Sasirangan is a traditional cloth from South Kalimantan produced by local craftsmen on a home industry scale. Sasirangan processing consists of dyeing and dyeing with synthetic dyes such as naphthol, indigosol, reactive, and indanthrene-this synthetic material results in a thick-colored liquid waste (Hardini et al., 2009).

Corresponding Author: Erpan Roebiakto

Medical Laboratory Technology Poltekkes Kemenkes Banjarmasin.

Mistar Cokrokusumo Street 4a Banjarbaru Indonesia 70714

Email: erfan.roebiakto4@gmail.com 
Liquid waste from sasirangan industrial activities has a high enough Chemical Oxygen Demand (COD) pollutant. This is because most of the waste produced is organic materials from the by-products of the coloring process using synthetic materials (Hadiwidodo et al., 2009). Waste released directly into water bodies can damage the environment, disturb the beauty, and be toxic to the water's organisms. Synthetic dyes also interfere with health because it is carcinogenic, which can be harmful to humans (Mizwar and Diena, 2012).

According to the Environmental Agency of the city of Banjarmasin (2017), the water quality of the Surgi Mufti river is polluted with COD levels reaching $240 \mathrm{mg} / \mathrm{L}$. Based on PP No. 82 of 2001 concerning Water Quality Management and Water Pollution Control. The COD level exceeds the quality standard limit of $10 \mathrm{mg} / \mathrm{L}$. The process of treating liquid waste needs to be done before the waste is disposed of in the environment or water bodies. This can be done through chemical processing with an adsorption process using corn cobs (Abuzar et al., 2014; Rahayu and Adhitiyawarman, 2014). According to Fitriani's research (2013), corn cobs are a readily available biomaterial, are still wasted, and also contain carbon compounds, namely cellulose (45\%), hemicellulose (35\%), and lignin (15\%) which are pretty high.

Based on Swastha's (2010) research, as much as $1.0 \mathrm{~g}$ of activated corncob charcoal was able to reduce COD levels of tofu waste from 540,672 mg / $\mathrm{L}$ to 417,792 $\mathrm{mg} / \mathrm{L}$ with a decreasing percentage of $22.88 \%$. In Amin's research et al. (2016), activated corncob charcoal can absorb $51.29 \%$ ammonia, $31.79 \%$ nitrite, and $58.71 \%$ nitrate with a soaking time of 10 minutes and a pH of 6.0. In Muthusamy's (2012) research, activated corncob charcoal reduced nickel content by $94 \%$ at a stirring speed of $200 \mathrm{rpm}$.

Corn cobs activated charcoal is proven to reduce ammonia, nitrite, nitrate, and nickel levels. There have also been studies using corn cobs to reduce COD levels in tofu waste, but the effectiveness of corn cobs charcoal in reducing COD levels of sasirangan waste has not been known. Sasirangan waste can become a new environmental problem, in line with the increase in the household scale sasirangan industry in South Kalimantan, Indonesia. So it is essential to handle this waste with active ingredients that are abundantly available in the area. The purpose of this study was to analyze the ability of corn cobs charcoal to reduce COD levels and increase the $\mathrm{pH}$ of sasirangan waste from home industries in South Kalimantan.

\section{MATERIALS AND METHOD}

The research material used was sasirangan industrial waste in Manarap Village, Kertak Hanyar District, Banjar Regency, South Kalimantan, Indonesia, with the examination being the levels of COD and corn cobs.

The process of making activated corn cobs charcoal uses heating at high temperatures (Ningsih et al., 2016) by washing the corn cobs with water until clean, then cutting them into small pieces, then drying them in the sun for 3-7 days, puree in a dry blender, dry again in the oven at a temperature of $105^{\circ} \mathrm{C}$ for 3 hours, then heated in a muffle furnace at $700^{\circ} \mathrm{C}$ for 2 hours, the last step, the charcoal is mashed and sieved with a 100 mesh sieve.

Wastewater samples are taken in a unique way that is free of other analytes and

acidified to a $\mathrm{pH} \leq 2$ to prevent the metabolic activity of microorganisms. Samples that 
have arrived at the laboratory are conditioned at $\mathrm{pH} 5$. The treatments for the samples consisted of 6 treatments, namely: without added activated charcoal; with the addition of $0 \mathrm{gr} ; 10 \mathrm{gr}$; 20gr; 30gr; 40gr; $50 \mathrm{gr}$ (6 treatments with three repetitions, $\mathrm{n}$ samples $=18$ ). As much as $1 \mathrm{~L}$ of sasirangan industrial waste with each treatment, stirred at a speed of 200 rpm for 15 minutes and left for 60 minutes, then filtered, do three repetitions.

Measurement of water content, ash, and lod number in the activated charcoal quality test is carried out at a unique waste measurement institute using the spectrophotometric method. The $\mathrm{pH}$ level is measured using a $\mathrm{pH}$ meter by dipping the electrode that has been cleaned and rinsed with analyte-free water into the test sample, then stirring slowly at a constant speed to be homogeneous until the $\mathrm{pH}$ meter shows a constant reading. Analysis of the color of wastewater samples and processed products was determined spectrophotometrically based on the standard color comparison method of the Platina-Cobalt solution. The color measurement results were given in $\mathrm{mg} / \mathrm{L} \mathrm{Pt}-\mathrm{Co}$ (Effendi, 2003). As for the turbidity level, the turbidimetry method was used.

COD levels were determined by the closed reflux titrimetry method. The COD inspection procedure begins with the standardization of the FAS solution. $2.5 \mathrm{~mL}$ sample add $1.50 \mathrm{~mL} 0.1 \mathrm{~N}$ potassium dichromate and $3.5 \mathrm{ml} \mathrm{H} 2 \mathrm{SO} 4$. Homogenize, reflux for 2 hours. Perform the titration with FAS using the ferroin indicator. COD values as $\mathrm{mg} / \mathrm{L}$ O2. The data obtained were analyzed using the Kruskal Wallis statistical test with a confidence level of $95 \%(\alpha=0.05)$.

\section{RESULTS AND DISCUSSION}

Table 1. Quality Test Results of Corncob Activated Charcoal

\begin{tabular}{ccccc}
\hline No. & Parameter & Unit & $\begin{array}{c}\text { Test } \\
\text { Results }\end{array}$ & $\begin{array}{c}\text { SNI 06- } \\
\mathbf{3 7 3 0 - 9 5}\end{array}$ \\
\hline 1 & Water Level & $\%$ & 11,84 & Max 15 \\
2 & Ash Level & $\%$ & 10,28 & Max 10 \\
3 & lod Number & g lodium/100g & 47,73 & Min 75 \\
\hline
\end{tabular}

Based on table 1, excellent activated charcoal has a maximum moisture content of $15 \%$ and a maximum ash content of $10 \%$. The resulting moisture content was $11.84 \%$ in this study, but the ash content exceeded the standard maximum limit of $10.28 \%$. In the study results, the iodine number of corn cobs activated charcoal is $47.73 \mathrm{~g}$ iodine / $100 \mathrm{~g}$; this indicates that the iodine number is still not close to the minimum limit of $75 \mathrm{~g}$ iodine/ $100 \mathrm{~g}$.

In table 2, the turbidity level in the sasirangan industrial waste without the addition of corncob-activated charcoal is $31.5 \mathrm{NTU}$. At a dose of $30 \mathrm{~g}$ and $40 \mathrm{~g}$, the turbidity level is 34.2 NTU and $34.6 \mathrm{NTU}$, but after adding a $50 \mathrm{~g}$, the turbidity level has decreased to 20.4 NTU. Sasirangan industrial waste before treated was conditioned five at $\mathrm{pH}$ value by adding strong acids; after treatment, the $\mathrm{pH}$ was increased. This research showed that the $\mathrm{pH}$ with a mass of 0 grams was 5.0 , but after adding $50 \mathrm{~g}$ of activated charcoal mass, the $\mathrm{pH}$ value increased to 8.6. The more mass of activated charcoal is added, the $\mathrm{pH}$ value increases in the Sasirangan industrial waste. The result of color intensity without the addition of corncob-activated charcoal is 3093 NTU. However, after activating charcoal mass by $50 \mathrm{~g}$, the color intensity has decreased to 2080 PtCO. 
Table 2. Average Results of Measurements of Turbidity Levels, $\mathrm{pH}$, and Color of Sasirangan Industrial Waste After Treatment

\begin{tabular}{cccc}
\hline $\begin{array}{c}\text { Corncob } \\
\begin{array}{c}\text { Activated } \\
\text { Charcoal } \\
\text { Weight (gram) }\end{array}\end{array}$ & $\begin{array}{c}\text { Turbidity } \\
\text { Level (NTU) }\end{array}$ & $\begin{array}{c}\text { Average } \\
\text { pH } \\
\text { Value }\end{array}$ & $\begin{array}{c}\text { Colour } \\
\text { Intensity } \\
\text { (PtCo) }\end{array}$ \\
\hline $\mathbf{0}$ & 31.5 & 5.0 & 3093 \\
$\mathbf{1 0}$ & 33.9 & 6.4 & 2643 \\
$\mathbf{2 0}$ & 27.0 & 7.1 & 2740 \\
$\mathbf{3 0}$ & 34.2 & 7.3 & 2410 \\
$\mathbf{4 0}$ & 34.6 & 8.1 & 2203 \\
$\mathbf{5 0}$ & 20.4 & 8.6 & 2080 \\
\hline
\end{tabular}

The efficiency level of decreasing the turbidity level of each treatment with the addition of activated charcoal of $0 \mathrm{~g}, 10 \mathrm{~g}, 20 \mathrm{~g}, 30 \mathrm{~g}, 40 \mathrm{~g}$, and $50 \mathrm{~g}$ can be determined by comparing the results of measurement of the intermediate turbidity levels without addition with the addition of activated corn cobs. Based on the research results, the addition of corn cobs activated charcoal by $50 \mathrm{~g}$ reduced an enormous turbidity level by a percentage of $35 \%$. The $\mathrm{pH}$ percentage of the Sasirangan industrial waste increased after the addition of activated corn cobs charcoal. The highest increase in $\mathrm{pH}$ was $72 \%$, with $50 \mathrm{~g}$ of activated corncob charcoal. Color reduction with $50 \mathrm{~g}$ of activated charcoal is $33 \%$ from $3093 \mathrm{PtCO}$ to $2080 \mathrm{PtCO}$. Based on table 3, it can be seen that the greater the activated charcoal added, the greater the percentage of color reduction and turbidity levels, as well as an increase in $\mathrm{pH}$ in the Sasirangan industrial waste.

Table. 3. Percentage of Decreased Turbidity Levels of Sasirangan Industrial Waste on 6 Treatments

\begin{tabular}{ccccc}
\hline \multirow{2}{*}{ Sample } & Dosage & \multicolumn{3}{c}{ Percentage } \\
\cline { 3 - 5 } & $\begin{array}{c}\text { Turbidity } \\
\text { Level }\end{array}$ & pH Value & $\begin{array}{c}\text { Colour } \\
\text { Intensity }\end{array}$ \\
\hline \multirow{3}{*}{$\begin{array}{c}\text { Sasirangan } \\
\text { industrial }\end{array}$} & 10 & $0 \%$ & $0 \%$ & $0 \%$ \\
waste & 20 & $-8 \%$ & $28 \%$ & $15 \%$ \\
& 30 & $-9 \%$ & $42 \%$ & $11 \%$ \\
& 40 & $-10 \%$ & $62 \%$ & $22 \%$ \\
& 50 & $35 \%$ & $72 \%$ & $29 \%$ \\
\multicolumn{2}{c}{ Meaning } & Decreased & Increased & Decreased \\
\hline
\end{tabular}

In table 4, it can be seen that the COD level of sasirangan industrial waste without the addition of corncob-activated charcoal is $1742.7 \mathrm{mg} / \mathrm{L}$. However, after adding $40 \mathrm{~g}$ of corncob-activated charcoal, the COD level decreased to $1298.4 \mathrm{mg} / \mathrm{L}$. However, with 
the addition of $50 \mathrm{~g}$ of corncob-activated charcoal, there was an increase in COD levels from the previous dose, which reached $1329.2 \mathrm{mg} / \mathrm{L}$

Table 4. Measurement Results of COD Levels of Sasirangan Industrial Waste After Treatment

\begin{tabular}{lrcccccc}
\hline \multirow{2}{*}{ Repetition } & \multicolumn{6}{c}{ Corncob Activated Charcoal Weight (gram) } \\
& $\mathbf{0}$ & $\mathbf{1 0}$ & $\mathbf{2 0}$ & $\mathbf{3 0}$ & $\mathbf{4 0}$ & $\mathbf{5 0}$ \\
\hline COD & $\mathbf{1}$ & 1724.0 & 1653.9 & 1541.8 & 1443.6 & 1373.6 & 1387.6 \\
Value & $\mathbf{2}$ & 1752.0 & 1583.8 & 1555.8 & 1457.7 & 1261.4 & 1303.5 \\
(mg/L) & $\mathbf{3}$ & 1752.0 & 1738.0 & 1569.8 & 1443.6 & 1260.2 & 1296.5 \\
\multicolumn{2}{l}{ Average } & 1742.7 & 1658.6 & 1555.8 & 1448.3 & 1298.4 & 1329.2 \\
\hline
\end{tabular}

The decrease in the COD level of industrial waste increased along with the increasing doses of corn cobs-activated charcoal. At a dose of $10 \mathrm{~g}$, there was a decrease in COD levels by $5 \%$, and after adding activated charcoal at a dose of $40 \mathrm{~g}$, the COD levels decreased by $25 \%$. The percentage reduction in COD levels can be seen in Table 5:

Table 5. Percentage of Decreased COD Levels of Sasirangan Industrial Waste At 6 Treatments

\begin{tabular}{ccccc}
\hline Sample & Dosage & Before & After & Efficiency \\
\hline & 0 & 1742.7 & 1742.7 & $0 \%$ \\
Sasirangan & 10 & 1742.7 & 1658.6 & $5 \%$ \\
Industrial & 20 & 1742.7 & 1555.8 & $11 \%$ \\
Waste & 30 & 1742.7 & 1448.3 & $17 \%$ \\
& 40 & 1742.7 & 1298.4 & $25 \%$ \\
& 50 & 1742.7 & 1329.2 & $24 \%$ \\
\hline
\end{tabular}

An analysis was carried out using the Kruskal Wallis statistical test to see the effect of the addition of corncob-activated charcoal on COD levels in the sasirangan industrial waste. Based on the test results obtained, $p$-value $=0.007$, which means $p$ is less than 0.05 . So it can be concluded that increasing the mass of activated charcoal on corn cobs on COD levels in the sasirangan industrial waste can be concluded. The Kruskal Wallis test results can be seen in Table 6 .

Table 6. Kruskal Wallis Test Results COD Levels in the Sasirangan Industrial Waste at 6 Treatments

\begin{tabular}{ccccc}
\hline & & $\mathrm{N}$ & COD Levels & $\mathrm{p}$-value \\
\cline { 2 - 5 } Mass of & 0 gram & 3 & $1752.0(1724.0-1752.0)$ & \\
Activated & 10 gram & 3 & $1653.9(1583.8-1738.0)$ & 0.007 \\
Charcoal & 20 gram & 3 & $1555.8(1541.8-1569.8)$ & \\
Corncob & 30 gram & 3 & $1443.6(1443.6-1457.7)$ & \\
& 40 gram & 3 & $1261.4(1260.2-1373.6)$ & \\
\hline
\end{tabular}


50 gram $3 \quad 1303.5(1296.5-1387.6)$

Note: Values are presented in median (minimum-maximum). Significance value $p<0.05$.

To find out which treatment groups had differences, the Man-Whitney post hoc test was performed. The results of the Man-Whitney statistical test analysis can be seen in table 7:

Table 7. Mann-Whitney Test Results

\begin{tabular}{ccccccc}
\hline & $0 \mathrm{~g}$ & $10 \mathrm{~g}$ & $20 \mathrm{~g}$ & $30 \mathrm{~g}$ & $40 \mathrm{~g}$ & $50 \mathrm{~g}$ \\
\hline $0 \mathrm{~g}$ & 0.000 & $0.121^{\mathrm{b}}$ & $0.046^{\mathrm{a}}$ & $0.043^{\mathrm{a}}$ & $0.046^{\mathrm{a}}$ & $0.046^{\mathrm{a}}$ \\
$10 \mathrm{~g}$ & $0.121^{\mathrm{b}}$ & 0.000 & $0.050^{\mathrm{b}}$ & $0.046^{\mathrm{a}}$ & $0.050^{\mathrm{b}}$ & $0.050^{\mathrm{b}}$ \\
$20 \mathrm{~g}$ & $0.046^{\mathrm{a}}$ & $0.050^{\mathrm{b}}$ & 0.000 & $0.046^{\mathrm{a}}$ & $0.050^{\mathrm{b}}$ & $0.050^{\mathrm{b}}$ \\
$30 \mathrm{~g}$ & $0.043^{\mathrm{a}}$ & $0.046^{\mathrm{a}}$ & $0.046^{\mathrm{a}}$ & 0.000 & $0.046^{\mathrm{a}}$ & $0.046^{\mathrm{a}}$ \\
$40 \mathrm{~g}$ & $0.046^{\mathrm{a}}$ & $0.050^{\mathrm{b}}$ & $0.050^{\mathrm{b}}$ & $0.046^{\mathrm{a}}$ & 0.000 & $0.275^{\mathrm{b}}$ \\
$50 \mathrm{~g}$ & $0.046^{\mathrm{a}}$ & $0.050^{\mathrm{b}}$ & $0.050^{\mathrm{b}}$ & $0.046^{\mathrm{a}}$ & $0.275^{\mathrm{b}}$ & 0.000 \\
\hline
\end{tabular}

Keterangan :

a: There is a meaningful difference

b: There is no meaningful difference

Table 7 shows that from the results of the Man-Whitney post hoc test, there were six treatments, there was no statistically significant difference, namely $20 \mathrm{~g}$ with $10 \mathrm{~g}, 40$ $\mathrm{g}$ with $10 \mathrm{~g}, 50 \mathrm{~g}$ with $10 \mathrm{~g}, 40 \mathrm{~g}$ with $20 \mathrm{~g}, 50 \mathrm{~g}$ with $20 \mathrm{~g}$ and $40 \mathrm{~g}$ with $50 \mathrm{~g}$. However, if seen from the percentage of efficiency in reducing COD levels, the addition of corncob activated charcoal with a mass of $40 \mathrm{~g}$ was the most effective compared to $10 \mathrm{~g}, 20 \mathrm{~g}, 30$ $\mathrm{g}$, and $50 \mathrm{~g}$.

Sasirangan industrial waste is the residual result of the activities of the Sasirangan cloth home industry. Based on the research results, the liquid waste's turbidity level decreased after adding $50 \mathrm{~g}$ of activated charcoal from 31.5 NTU to 20.4 NTU (with a percentage reduction of $35 \%$. This makes it clear that the addition of corncob activated charcoal activated with $4 \mathrm{~N} \mathrm{HCl}$ is $12 \mathrm{~g}$. able to reduce water turbidity from $75 \mathrm{NTU}$ to 19.84 NTU with a decreasing percentage of $73.54 \%$ (Munifiah, 2015).

The addition of contaminant-activated charcoal in the liquid waste will be absorbed due to the pull from the surface of the charcoal, which is stronger than the vital force that holds it in the solution. The fewer contaminants in the liquid waste, the less light is dissipated to decrease the turbidity rate. The decrease in unstable turbidity is caused by the large amount of organic and inorganic material produced from the residue of the sasirangan cloth coloring process (Syauqiah, 2011).

The increase in $\mathrm{pH}$ of the Sasirangan industrial waste occurs in line with the increase in the mass of activated charcoal. Based on the research results, the addition of mass of activated charcoal by $50 \mathrm{~g}$ increased the $\mathrm{pH}$ from 5.0 to 8.6.

The increase in $\mathrm{pH}$ occurs because activated charcoal is polar to adsorb water after contact with Sasirangan industrial waste (Pari, 2004). In addition, the functional groups formed on activated carbon occur due to the interaction of free radicals on the carbon surface with oxygen and nitrogen atoms from the atmosphere. The existence of 
this functional group makes activated carbon chemically reactive so that activated carbon can be acidic or alkaline (Murti, 2008).

In this study, corn cobs-activated charcoal can also reduce the color intensity of the sasirangan industrial waste. The addition of activated charcoal with a mass of $50 \mathrm{~g}$ in $1 \mathrm{~L}$ has the highest removal effectiveness of $32 \%$ from $3093 \mathrm{PtCO}$ to $2080 \mathrm{PtCO}$. This proves that the addition of $6 \mathrm{~g}$ of activated charcoal decreases the color intensity from $3200 \mathrm{PtCO}$ to $1947 \mathrm{PtCO}$ with a decreasing percentage of $39.16 \%$ (Mizwar, 2012). The increase in the mass of the adsorbent will cause the number of particles to increase and the abundance of surface area and space from the pores that can absorb adsorbate (Alfiany, 2013).

However, with the addition of $20 \mathrm{~g}$ of mass, there was a decrease in the adsorption capacity of activated charcoal on the color of the sasirangan industrial waste. This is because the adsorbate's contact time and the adsorbent have exceeded the optimum time so that the desorption process occurs. Desorption is the process of releasing ions or molecules that have bound to the adsorbent (Ningsih, 2016).

The low effectiveness of the highest color absorption is $32 \%$, due to the high content of organic matter (COD $1742.7 \mathrm{mg} / \mathrm{L}$ ) and the concentration of turbidity (31.5 NTU) in the sample of Sasirangan industrial waste. As a result, there is a competition to absorb these adsorbate substances by activated charcoal (Mizwar, 2012).

Sasirangan industrial waste is the residual result of the activities of the Sasirangan cloth home industry. One of the parameters of textile industry waste is COD. According to Alaerts and Santika, COD levels are the amount of oxygen (mg O2) needed to oxidize organic substances in one liter of liquid samples with organic sources derived from chemicals, namely K2Cr2O7 (Alaerts and Santika, 1984). Based on the study results, the COD content contained in the sasirangan industrial waste without the addition of corncobactivated charcoal was $1742.7 \mathrm{mg} / \mathrm{L}$ (Table 4). According to governor regulation No. 36 of 2008 concerning Quality Standards for Waste for the Textile Industry, the liquid waste still exceeds the established quality standard limit of $150 \mathrm{mg} / \mathrm{L}$.

According to Alaerts and Santika, a high COD number indicates that the waste contains high organic substances. The high content of organic substances will reduce dissolved oxygen content in water (Alaerts and Santika, 1984). Therefore it is necessary to do the processing first before discharging it to the water body. The adsorption process of sasirangan industrial wastewater organic compounds with the addition of activated charcoal on corn cobs reduced COD levels by $25 \%$ in the treatment with 40 grams of activated charcoal mass. According to previous research, the more mass ratio of activated charcoal added to the industrial waste of Sasirangan, the more active charcoal pores will adsorb organic substances in the waste of Sasirangan industry (Siregar et al., 2015).

The adsorption process occurs because of the van der walls force. The carbon atoms on the surface of the solid have an unbalanced force compared to the arrangement of atoms in the substance in general, so that foreign molecules will try to fulfill the imbalance (Manocha, 2003).

However, when the mass of activated charcoal was added to $50 \mathrm{~g}$, the absorption ability decreased. Table 7 also shows no significant difference between the addition of low mass activated charcoal treatment $(10 \mathrm{gr}$ and $20 \mathrm{~g}$ ) and $50 \mathrm{~g}$. This is in line with research conducted in 2015 that the absorption ability of COD decreased after the 
addition of $6 \mathrm{~g}$ of kapok seed-activated charcoal. This happens because the increasing number of adsorbents causes the adsorbent to reach its saturation point if the surface has been filled with adsorbate (Siregar et al., 2015).

Besides reducing COD levels, activated corn cobs can also reduce turbidity and color in sasirangan industrial waste. The magnitude of the attractive color and turbidity with the adsorbent causes absorption competition between contaminants and organic substances, which results in a disturbed COD adsorption process. So that the adsorption capacity of organic substances is reduced in the presence of other adsorbates (Abuzar, 2014), according to Swastha (2010), increasing pH also affects the adsorption process because, in high $\mathrm{pH}$ conditions, the number of $\mathrm{OH}$ - ions will be abundant which causes the diffusion process of organic matter to be disrupted (Swastha, 2010).

In addition, the low absorption percentage of COD levels is also influenced by the quality of activated charcoal. The percentage of corn cob charcoal ash content was $10.28 \%$; Exceeds the maximum limit of $10 \%$ (Table 1); according to a 2015 study, an increase in the percentage of ash content causes the formation of mineral salts during the charring process so that the clogging of the pores of activated charcoal causes the surface area of activated charcoal to decrease (Maulinda, 2015).

The number of disturbing factors such as ash content that exceeds the maximum limit, iodine number, which has a low absorption value, and the absorption competition between turbidity, color, $\mathrm{OH}$ - ions, and organic substances in the adsorption process causes the efficiency of reducing COD levels to be less than optimal. Thus, corn cobsactivated charcoal is less effective in reducing COD levels in the Sasirangan industrial waste. However, if this adsorption waste treatment is applied, it should be used at the pretreatment stage or carried out on wastes with low COD levels.

This study has limitations on the sample of Sasirangan waste which is only limited to one industrial house. There may be differences in the results of COD reduction in each sasirangan industrial house due to the different types of dyes used for the manufacture of Sasirangan fabrics.

\section{CONCLUSION}

The COD levels of sasirangan industrial waste decreased with the addition of corncob activated charcoal at the highest dosage of $30 \mathrm{gr}, 40 \mathrm{gr}, 50 \mathrm{gr}$ with the percentage of decreasing respectively, namely 24 percent, 35 percent, and 33 percent. An increase in $\mathrm{pH}$ was found at the same dose of 46 percent, 62 percent, and 72 percent, respectively. There is an effect of increasing the mass of activated charcoal from corn cobs on COD levels in the Sasirangan industrial waste with a significance value of 0.007 . It is suggested to use corn cobs-activated charcoal for the pretreatment stage of sasirangan industrial waste treatment.

\section{ACKNOWLEDGEMENT}

None declared.

\section{CONFLICT OF INTEREST}

There were no conflicts of interest with related parties in this study.

\section{REFERENCE}


Abuzar, S. S., \& Dewilda, Y. (2014). Analysis of Chemical Oxygen Demand (COD) Removal for Hotel Liquid Waste Using Corn Husk Powder. Jurnal Dampak, 11(1), 18-27.

Alaerts, G., \& Santika, S. S. (1987). Water research method. Usaha Nasional. Surabaya, 309.

Alfiany, H., Bahri, S., \& Nurakhirawati, N. (2013). Study on the Use of Corncob Activated Charcoal as $\mathrm{Pb}$ Metal Adsorbent with Several Acid Activators. Natural Science: Journal of Science and Technology, 2(3).

Amin, A., Sitorus, S., \& Yusuf, B. (2016). Utilization of corn cobs (Zea mays L.) as active charcoal in reducing levels of ammonia, nitrite, and nitrate in tofu industrial wastewater using dipping techniques. Jurnal Kimia Mulawarman, 13(2).

Effendi, H. (2003). Telaah kualitas air, bagi pengelolaan sumber daya dan lingkungan perairan. Kanisius.

Fitriani, F., Bahri, S., \& Nurhaeni, N. (2013). Production of Corn Cobs Bioethanol (Zea Mays) from the Delignification Process. Natural Science: Journal of Science and Technology, 2(3).

Ginting, I. P. (2018). Environmental and industrial waste management systems.

Hadiwidodo, M., Huboyo, H. S., \& Indrasarimmawati, I. (2009). The reduction of color, cod and tss of textile industrial wastewater uses dielectric barrier discharge technology with variations in the voltage and flow rate of oxygen. Jurnal Presipitasi: Media Komunikasi dan Pengembangan Teknik Lingkungan, 6(2), 16-22.

Hardini, R., Risnawati, I., Fauzi, A., \& Komari, N. (2009). Utilization of Alang-Alang Grass (Imperata cylindrica) as Biosorbent $\mathrm{Cr}(\mathrm{VI})$ in Sasirangan Industrial Waste with the Tea Bag Method. Jurnal Sains dan Terapan Kimia, 3(1), 57-72.

Manocha, S. M. (2003). Porous carbons. Sadhana, 28(1-2), 335-348.

Maulinda, L., Nasrul, Z. A., \& Sari, D. N. (2017). Utilization of cassava peels as raw material for activated carbon. Jurnal Teknologi Kimia Unimal, 4(2), 11-19.

Mizwar, A., \& Diena, N. N. F. (2012). Removal of Color in Sasirangan Industrial Wastewater with Activated Carbon Adsorption. Info-Teknik, 13(1), 11-16.

Murti, S. (2008). Preparation of Activated Carbon from Corn Cob for Adsorption of Ammonia Molecules and Chrome lons. Universitas Indonesia, Depok.

Muthusamy, P., Murugan, S., \& Smitha, M. (2012). Removal of nickel ion from industrial wastewater using maize cob. International Research Journal of Biological Sciences, 1(2), 7-11.

Ningsih, D. A., Said, I., \& Ningsih, P. (2016). Lead metal (Pb) adsorption from the solution using adsorbent from corn cobs. Jurnal Akademika Kimia, 5(2), 55-60.

Pari, G., Sofyan, K., \& Syafii, W. (2004). Activated Charcoal As Formaldehyde Capture In Plywood. Journal of Agroindustrial Technology, 14(1).

Putra, M. R. A. (2011). Analysis of the role of the Sasirangan cloth industry on the economy of the city of Banjarmasin and its development strategy. Thesis at the Faculty of Economics and Management, Bogor Agricultural University. Bogor..

Rahayu, A. N. and Adhitiyawarman. (2014). Utilization Of Corn Cob As Iron Adsorbent In Groundwater. Jurnal Kimia Khatulistiwa, 3(3).

Syauqiah, I., Amalia, M., \& Kartini, H. A. (2011). Analysis of variations in time and speed of stirrer in the adsorption process of heavy metal waste with activated charcoal. Info-Teknik, 12(1), 11-20. 
Swastha, J. T. (2010). The ability of activated charcoal from cassava peels and corn cobs to reduce levels of $C O D$ and BOD of tofu factory waste (Doctoral dissertation, Universitas Negeri Semarang). 